\title{
THE INFLUENCE OF THE SOCIAL SCIENCE ASSOCIATION ON HOSPITAL PLANNING IN VICTORIAN ENGLAND
}

by

\author{
MICHAEL MILLMAN*
}

The LAMENT in Tennyson's In Memoriam, "So many worlds, so much to do,/So little done, such things to be," all but characterizes the attitude of the Victorians, who, though shocked by the discovery of social ills within their society, confidently set about to solve their problems with grave determination. New knowledge in the social and natural sciences seemed to promise a means of recovery from some of the painful side-effects of urbanization. All that was needed was proper application of this new knowledge through organized effort.

In the health field, the sanitary revolution was the major attraction of the day. However, other complementary movements, such as hospital reform, occupied the energies of a number of prominent individuals. The cities, unable to meet the sanitary needs of a rapidly growing population, likewise, had not planned adequately to meet the medical needs of those dependent on hospitals. An organization called the Social Science Association served as a focal point for those who sought a better way of delivering medical services through a well-organized hospital system. At first, these hospital reformers carried out their investigations under the aegis of the Social Science Association, which sponsored England's first Hospital Conference. That which concerned the participants of this conference bears a remarkable resemblance to the concerns of modern American health planners. Later, after the parent organization disbanded, a splinter group continued the work of bringing the failings of Britain's hospital system before the government and the general public.

\section{THE SOCIAL SCIENCE ASSOCIATION}

The National Association for the Promotion of Social Science belonged to that group of learned societies in the nineteenth century that provided a centre where specialists could meet, read and discuss papers, and promote their ideas. The pressure exerted by these societies had a great deal to do with advancing the acceptance of the social sciences as academic disciplines in the British universities. ${ }^{1}$

The National Association for the Promotion of Social Science (more commonly known as the Social Science Association) was founded on 29 July 1857, when a group of prominent intellectuals gathered at the home of Lord Brougham. Their purpose was to unite all those interested in social improvement, and they could count among their number such men as John Stuart Mill, Edwin Chadwick, John Simon, and William Farr. ${ }^{2}$

*100 Haven Avenue, Apt. 19E, New York, N.Y. 10032, U.S.A.

Medical History, 1974, vol. 18. 


\section{The Influence of the Social Science Association on Hospital Planning in Victorian England}

The founders divided the association into five departments-Law Amendment, Education, Prevention and Repression of Crime, Public Health, and Social Economy. Every year in a different city the association would hold a congress and publish the Transactions. Each department, led by a group of officers, would carry on the work of the association during the year.

The annual congresses were colourful affairs, and cities would compete to be the hosts. The leaders of the association chose Birmingham to hold their first meeting on 12 October 1857. The Times gave extensive coverage to these proceedings and printed almost complete texts of the speeches delivered by Lord Brougham and the five department chairmen. ${ }^{3}$

For close on thirty years the Social Science Association proved to be a potent political force. The members, for the most part, were practically oriented and deeply involved in carrying out the business of the Empire. Lord Brougham's inaugural address clearly set the association on a course of policy impact as he stated their intentions to "aid legislation, by preparing measures, explaining them, by recommending them to the community, or, it may be, by stimulating the Legislature to adopt them."4 This orientation never altered, as evidenced by Lord O'Horgan's remarks on the twenty-fifth anniversary of the Association:

For a quarter of a century labouring, not at your Congresses only, but at frequent meetings, in every month, in London, your active members have watched the progress of legislation: ascertaining and arranging facts on questions of current interest; formulating Parliamentary enactments: urging the appointment of Parliamentary Committees: and circulating reports for the guidance of opinion, in Parliament and out of it, which have had a very appreciable and a very salutary influence. ${ }^{b}$

The members of the Council of the Social Science Association alone proved to be a sizeable legislative bloc. In 1882, this Council could boast sixty-four members of parliament, thirteen lords, and thirteen earls. ${ }^{6}$

\section{THE PUBLIC HEALTH DEPARTMENT}

In his inaugural address at Birmingham, Lord Stanley, chairman of the Public Health Department, prophetically declared that "State provision of medicine is a controversy that will be renewed in various shapes". "The Public Health Department of the Social Science Association was in many ways advanced for its time in health considerations that still plague nations today. They, too, worried about alcoholism, pollution, occupational diseases, and the health effects of poverty. However, what is more important than the issues, themselves, that concerned the members of the Social Science Association is the way in which they looked at health problems and attempted to solve them. Here, perhaps, may be found the roots of what we call health planning.

"Planning" is one of those dangerous terms, like "policy" or "evaluation", that is never defined to the satisfaction of everyone. Most often "planning" is described as a process with various stages. ${ }^{8}$ Common to almost all definitions, nevertheless, are the stages of goal setting, data gathering, and development of a strategy or proposal for action.

We tend to think of health planning as exclusively a modern activity. However, 


\section{Michael Millman}

the Social Science Association tried to look at the health problems of the nineteenth century in a conscious, organized fashion that in many ways resembles the efforts of modern health planners. In particular we will focus on hospital planning and those individuals instrumental in attacking the problems of the British hospital system.

From the first year of the Social Science Association, the Public Health Department determined a method by which it would proceed. The papers to be read at the congress were selected on the basis of three classifications: (1) the actual condition of the public health, past and present; (2) the causes which modify it, whether favourably or adversely; (3) the consideration of preventive or palliative measures. ${ }^{9}$ In effect, this scheme follows the overall aims of the Association-"to collect facts, diffuse knowledge, stimulate inquiry, and suggestions for the aid of social improvement." 10

The overriding goal of the Public Health Department was stated by Lord Stanley when he said, "We aim at reducing the deaths in every employment, and in all inhabited localities, to the level of those which occur in the healthiest employments and in the healthiest localities."11 Specific priorities for action on this broad goal shifted from year to year and often depended upon data-gathering activities. For example, many studies were carried out by association members on the sanitary conditions of specific towns and populations. As a result of this statistical information, a movement toward health education began. The female members of the Social Science Association created an in-service training programme for school-mistresses so that they might instruct the children of the lower classes in the importance of hygiene. These ladies also compiled "interesting, simple, and practically written tracts" on all subjects of preservation of health. ${ }^{12}$

In this period, statistical techniques were not widely appreciated by all those influencing health policy. Many members of the Social Science Association worked to improve ways of describing health conditions. One early paper criticizes medical men who would rather watch than count. ${ }^{13}$ Such questions as "Is the death rate an indicator of the sanitary conditions of a country?" were being pondered in the search for better measurement techniques. ${ }^{14}$ Continuing Chadwick's earlier work, comparative studies abounded on the topics of effects of poverty and privation on health, as well as studies on the health status of special populations.

The search for data on the nation's health soon spread to the hospitals. At first, investigators concerned themselves with the poor sanitary conditions and construction of the hospital. Later, men like Henry C. Burdett, Timothy Holmes, and T. GilbartSmith examined the organization, financing, and delivery of hospital services. The results of these studies led to agitation for hospital reform in the 1880s. The Social Science Association provided a focus for this agitation by sponsoring Britain's first Hospital Administration Conference, the outgrowth of which was the formation of an Association of hospital administrators.

\section{A GROWING CONCERN-1857 to 1880}

One of the problems that most concerned those presenting papers to the Department of Health was the construction and sanitary conditions of hospitals. Appropriately, then, one of the first major speakers at a Social Science Congress was Florence Nightingale, the century's great crusader for hospital reform. Miss 


\section{The Influence of the Social Science Association on Hospital Planning in Victorian England}

Nightingale was among the first to recognize the relationship of poor hospital conditions to a hospital's mortality rates and believed that the latter could be diminished. Her methods of comparing different hospitals shows a relatively high degree of sophistication: "The proportion of recoveries, the proportion of deaths, and the average time in hospitals must be taken into account in discussions of this nature, as well as the character of the cases and the proportion of different ages among the sick." 15 She realized that one could not merely compare hospitals on the basis of mortality figures, as was commonly done.

Florence Nightingale attempted to apply the best scientific knowledge of the time and her own empirical observations of hospitals throughout the world to hospital planning and construction. This led her to criticize institutions for overcrowded wards, lack of space, and deficiency of light and ventilation. She scrutinized all aspects of hospital construction and equipment, from the arrangement of the beds to the types of furniture that should be used. ${ }^{16}$

Other veterans of British military medicine also provided their experiences on how hospitals should be built. Robert Rawling, a Commissioner of Sanitary Engineering to the Army in the Crimea, in 1858 offered a host of suggestions relative to water supply, elevation of the land, the materials from which sewers and pipes should be made, and how the building must be heated.17

Some planners of the time proposed quite complex methods of dealing with hospital construction. One engineer in 1862 described an elaborate method of artificially ventilating hospital wards..$^{18}$ However, according to his detractors, the best means of ventilating hospitals was still by the ordinary one of opening windows and burning fires. ${ }^{19}$

The popular new concept in hospital design of the day was the pavilion style-a style that Florence Nightingale strongly advocated. This, of course, did not stop others from trying to invent even more efficient designs. John Marshall, for instance, proposed a circular system of wards, which would take into account light, space, heating, ventilation, and isolation. ${ }^{20}$

It is interesting to note how hospital administrators were beginning to realize that wise planning was also a boon to hospital economy. One small example of this is John Charles Steele's paper on hospital dietetics. Among a number of observations on how to save money in the hospital kitchen, Steele noticed that "The small loss sustained by baked meat in comparison with roast meat is very remarkable." 21

It was becoming clear to many in the health field that the general hospital was not always the appropriate facility for caring for certain patients. Thus, the merits of convalescent homes and sanatoria were being vaunted. The concept of continuous care, perhaps, had its roots in a number of these institutions. The purpose of a convalescent home was described as "some restorative provision for poor patients, intermediate between the hospital wards and their own homes." 22 Gaskell, in 1861, could well have been depicting a modern psychiatric half-way house when he spoke of the need for "a class of houses intermediate between the patient's home and a lunatic asylum, in which only a certain amount of restriction should be exercised over the inmates." 23 


\section{Michael Millman}

Throughout the first twenty-five years of the Social Science Association, the realization that something was wrong with the country's hospitals was transformed into a cause célèbre among the members of the association. The mode of treating the nation's sick was called "the greatest blot in our sanitary system". ${ }^{24}$ People spoke of the "evils of medical charities". ${ }^{25}$ Catherine Tolson Duck charged that "patients are victims of the negligence and ignorance of hospital governors". ${ }^{26}$ To be sure, hospital abuse was not given the highest priority at every congress. Yet, at the start of the 1880s, everyone's attention quickly focused on the hospital and the great political weight of the Social Science Association was brought to bear on the problem.

\section{A CALL FOR GOVERNMENT INTERVENTION-1881 to 1883}

At the Dublin Congress of 1881, Henry C. Burdett delivered a paper on the topic of "Is it desirable that Hospitals should be placed under State Supervision?" In response to the demand for the information presented in his paper, the author published his materials in a small volume entitled Hospitals and the State.

Burdett, perhaps more than anyone else, was responsible for the zeal with which the Social Science Association pursued the goal of better hospital planning. Though knighted later in his life, Burdett was born into the middle class in 1847. He began his career working in a bank, but, after an illness, became Secretary of Queen's Hospital in his native Birmingham. He then moved on to become Secretary at the Seamen's Hospital. In 1896, Burdett was appointed Vice-President of the Seamen's Hospital Society-a very unusual advancement, for a secretary of a hospital seldom rose to the ranks of vice-president.

In his extensive travels on the Continent and in America, Burdett visited many medical institutions, which he described in Hospitals and asylums of the world and Pay hospitals of the world. He also founded the publications Burdett's hospital annual and The hospital. However keen his interest in hospitals, Burdett had a wide range of other concerns, as well. For a time, he was secretary of the Stock Exchange. Early in life he pursued his fascination with political organization, one of his companions being Joseph Chamberlain. Years later, Gladstone was known to have consulted Burdett on a number of occasions on such matters as Home Rule and the Irish Constitution. ${ }^{27}$ Perhaps, this combined interest in government and in hospitals allowed Burdett to see the potential of government intervention in health care-a concept he would investigate many times until his death in 1920.

Hospitals and the State was predicated on Burdett's fear that the system of hospitals could not much longer continue unaltered and unreformed. Burdett describes the past efforts of four deputations to the Secretary of State for the Home Department to obtain a Royal Commission of Investigation. The first two deputations consisted of representatives of the leading metropolitan hospitals; the third deputation was composed of representatives of patients; and the fourth comprised members of the British Medical Association.

The paper is an attempt by Burdett to distil the argument for state interference "with the view of putting into motion the powerful organisation which the Social Science Association has at its command." ${ }^{28} \mathrm{He}$ divides the question into seven propositions for review. 


\section{The Influence of the Social Science Association on Hospital Planning in Victorian England}

The first proposition concerns the maldistribution of hospital facilities in the metropolis. Within the radius of 1.5 miles from Charing Cross in London, there existed nine-tenths of the total hospital beds available in the city. Other areas of London, however, were in great need of hospital facilities. For example, north London, with a population of $1,000,000$ contained only two hospitals, a total of fifty-nine beds. Burdett also noted discrepancies in the operating costs of hospitals -a difference of twenty-five per cent in the cost of management and 500 per cent in the cost of maintaining a patient at different institutions. While some hospitals were starving, others wallowed in "reckless and culpable extravagance". One of the pavilions at St. Thomas's, for instance, was turned into what Burdett describes as a palace for the personal use of the treasurer. Later in his essay, Burdett speaks of the "building mania" that blinded managers. The resultant construction produced in certain districts half-empty wards, which, in turn, increased the cost of maintenance. ${ }^{29}$

Secondly, the author addresses himself to the problems of outpatient hospital care. In London, more than 1,000,000 people annually availed themselves of free medical relief. The average waiting time was three to seven hours and the care was merely perfunctory. ${ }^{30}$

The third and fourth proposition dealt with governance and administration. In Burdett's view, hospitals would best be managed through a board elected by the governors with adequate input from the medical staff. A system of public audit and review would be necessary to check extravagance and protect the public's safety. Once again the author illustrated his case of hospital mismanagement by alluding to the scandals involving the three large endowed hospitals (Guy's, St. Bartholomew's, and St. Thomas's). ${ }^{31}$

In the fifth proposition, "organisation and combination" among medical institutions was hailed as the answer to extravagance, repetition of expenditure in the management of charities, problems of finance, accounts, and supplies, and the relationship of hospitals to dispensaries. Reminiscent of modern hospitals' attempts to co-operate on such matters as laundry service, Burdett recommends the creation of a central store where all hospitals might purchase supplies at just above the cost price. Similarly, he suggests that charitable agencies combine to avoid multiple and duplicate appeals. ${ }^{32}$

The last two propositions attack the problems of nursing and medical education. Paradoxically, Burdett opposed nursing schools in clinical hospitals while vehemently supporting close relationships between hospitals and their medical schools. He has harsh words for hospitals that leave patients in the care of a "raw practitioner who knows next to nothing about nursing". On the other hand medical students are an asset to a hospital for they render teachers still more efficient in the wards and administer to the comfort and well-being of the patient. ${ }^{33}$ Burdett's attitude toward nurses eventually changed.

Burdett never answers the question of whether the State should control hospitals; rather, he states that his intentions were merely to bring facts to the notice of the congress and to demonstrate that the time was ripe for an inquiry by a Royal Commission. He hints that the Home Secretary, Sir William Harcourt, was favourably disposed toward a commission, and "there is good reason to believe he may be 


\section{Michael Millman}

induced to grant an inquiry at the instigation of the Social Science Association". ${ }^{34}$ The participants of the Dublin Conference met Burdett's call for a Royal Commission with a resolution, unanimously arrived at, to establish a committee to study the ramifications of such a government commission. Under the leadership of Sir T. Fowell Buxton, the committee which included Henry Burdett, Timothy Holmes, and Francis Powell, spent several months examining the issue and eventually presented to the council of the Social Science Association a resolution urging that a memorial be sent by deputation to the Home Secretary. The council adopted the memorial in March 1882; however the Home Secretary preferred that the association's views be sent to him in writing rather than by deputation. The memorial enumerated eight reasons-ranging from the maldistribution of hospitals to the financing of medical charities-why an investigation should take place. ${ }^{35}$

Still, the Government did not exhibit any interest in taking action on the question of a Royal Commission, so that by the next congress of the association in September 1882, the subject was raised again. Dr. T. Gilbart-Smith, of the London Hospital, prepared a paper entitled "What reforms are desirable in the Administration of Hospitals".

He reiterated many of the points that Burdett raised the year before in addition to some of his own pet concerns. One of Gilbart-Smith's interests was the establishment of a London ambulance service. As a result of the poor distribution of hospitals in the metropolitan area, often patients did not complete the journey to the hospital without serious complications. Gilbart-Smith said that he could not understand how third- and fourth-rate American cities had ambulance services in good working order, while London still struggled along with its outmoded system..$^{36}$

Concern over hospital construction was still an issue as it had been when Florence Nightingale broached the subject with the Social Science Association. Gilbart-Smith noted: "Building after building has of late been erected, which exhibit unpardonable errors, and show a persistent disrespect of what is considered essential in such structures." 37 He gave the example of Westminster Hospital's outpatient department, which was located in the basement next to the dissecting-room.

Gilbart-Smith's arguments on the side of hospital reforms brought forth a resolution to convene a conference of hospital managers from all sections of the kingdom. The idea of such a conference was proposed as early as 1878 , by Henry Burdett in a letter to The Times: "We have all much to learn and if the combined experience of all of the managers of the medical charities could be made available for the guidance and advantage of each and all the hospital committees of this country, the result could not but produce much economy and advantage to the hospitals and the public". ${ }^{38}$ These sentiments were reaffirmed the next year when several hospital administrators met at the house of T. Fowell Buxton. They expressed the opinion that for the past two to three years the funds of the large hospitals were not being applied in the best possible manner. The situation needed the remedy of a Royal Commission. ${ }^{39}$

THE FIRST HOSPITAL ADMINISTRATION CONFERENCE

After much preparation, the conference was held on 3 and 4 July 1883, in the 


\section{The Influence of the Social Science Association on Hospital Planning in Victorian England}

hall of the Society of Arts in London. The Lancet published several articles encouraging attendance at the Conference. "We wish the attempts of the Social Science Association all success and congratulate them on the public spirit and enterprise they have shown by undertaking to organise and bear the expense of promoting the first Hospital Conference." 40

The conference was to serve two basic purposes-one didactic and one political. The papers read at the conference were to be collected and become what chairman Francis Powell described as "a textbook upon the subjects which had occupied their attention ... a repertory of the latest and best information wherein might be found the best and most mature thoughts of our most advanced thinkers upon those subjects". ${ }^{41}$ As for the political aspects of the conference, the tone was set from the opening address and continued to the closing words of the last session: there must be a Royal Commission to study the problems of hospitals. Powell began the proceedings with a reminder of the Home Secretary's rebuff and with the hope that some reforms might come from the meeting. In the next two days, fourteen papers were read on the subjects of hospital administration, outpatient departments, finance, convalescent institutions, and, finally, the necessity for a Royal Commission.

The problems of administration centred mainly around the constitution of hospital governing boards, the relationship of physicians to these boards, and the relationship of the hospitals to medical schools. B. Burford Rawlings of the National Hospital for the Paralysed and Epileptic complained of the impracticality of relying on donors to assist in the management of the hospital. "Would any man entrust the management of his enterprises to a committee never likely to be constituted twice alike during the year?" remarked Mr. Rawlings. ${ }^{42}$ Dr. J. S. Bristowe of St. Thomas's spoke of the plight of the medical men who had but little contact with the 200 to 300 governors of his hospital. Bristowe desired to see members of the medical and surgical staff elected to the hospital councils so that more frequent interchange might occur. ${ }^{43}$ The problem of insecure and ill-endowed medical education was introduced by T. Gilbart-Smith, who felt that medical schools were necessary for the effectual operation of clinical hospitals. ${ }^{44}$

In the discussion that followed the papers on hospital administration, the participants generally agreed on the principle of accountability, a small number of administrators on whose shoulders would rest the responsibility of proper hospital operation. On the suggestion of State intervention, the representative from King's College Hospital noted that in his experience, the Local Government Board was helpful with respect to infirmaries that were badly managed but, at the same time, hampered progressive reforms in those institutions that were well managed. ${ }^{45}$ Although Henry Burdett supported the concept that successful medical schools meant successful hospitals, others, like G. B. Lloyd of the General Hospital at Birmingham, did not agree. "The General Hospital at Birmingham", said Lloyd, "was managed as far as possible in the interests of the patients, while some other hospitals had been managed in the interests of the students rather than in the interests of the patients." 46

When the proceedings turned to the matter of outpatients and systems of free and 


\section{Michael Millman}

pay beds, the supporters of the Provident Societies presented their case. It was their opinion that the abuses of the hospital system were a result of attempts to relieve all the sickness of the poor through gratuitous charity without differentiating between what disease should be treated and which patients were, indeed, deserving of charity. In an observation that practically foreshadows utilization review, Timothy Holmes pointed out that not all types of illnesses need to be treated in the hospital. ${ }^{47}$

The advantages of provident dispensaries for which clients could contribute money weekly to insure themselves against times of illness, were promoted on several counts. First of all, the poor would no longer be encouraged to be dependent as they were in the present system. The institution of the family doctor, who could become familiar with the peculiar habits of the family, advise on prevention, and provide sanitary education, would now be extended to the working class. It was also hoped that the poor as a result of the provident dispensaries, would follow the example of the upper classes and not crowd the hospital. This would restore the functions of the hospital outpatient department as consultative..$^{48}$

The abuses of the outpatient departments were graphically described by Sir Charles Trevelyan in what he called the "break-down of the system": "After hours of waiting in a crowded and infectious room, all that the patients could look for was an infinitesimal fraction of the time of an overworked medical man who never saw them before, and would probably never see them again, and who had to make his diagnosis in this very short time".49

On the second day of the conference, Henry Burdett single-handedly tackled the knotty problems of hospital finance and audit. Burdett's paper is an attempt to look at the fiscal problems of hospitals in a logical and organized fashion. He decried the fact that few hospital administrators realized the importance of treating the financial management of their institutions in a businesslike and intelligent way, and he proceeds to instruct them in such basic economic techniques as the following: " . . . every three months, prepare a budget estimate of the income and expenditure for the ensuing three months with the view of ascertaining how much income will probably be forthcoming, and how the deficiency, if deficiency there be, is to be met."50

In his research for the paper, Burdett was appalled at the manner in which hospital accounts were kept. Most hospitals did not even keep a balance sheet, but merely an incomplete collection of receipts and payments. Thus, one of the main objectives of the essay was to impress upon the hospital managers that in order to plan wisely they had to keep accurate records of their income and expenditure.

Burdett's investigation led him to the conclusion that metropolitan hospitals were spending annually $£ 40,000$ in excess of their income. One of the major causes of this deficit was the decrease in income from voluntary sources due to increased competition among charities, especially some of the smaller, special hospitals that had only recently appeared on the scene. St. George's in 1873 received $£ 15,449$; this fell to $£ 10,691$ in 1881 . In that same period Westminster Hospital's income fell from $£ 4,855$ to $£ 2,993$. The author's remedy for the situation revolved around a decentralization of hospitals from their valuable sites in the saturated central region to the densely populated neighbourhoods. Each general hospital could then map out its own territory where both charitable relief and charitable contributions could be 


\section{The Influence of the Social Science Association on Hospital Planning in Victorian England}

localized. This utilizes the principle that people are more likely to donate to charities that are visibly accomplishing relief in their own districts. ${ }^{51}$

Although much of the controversy at the conference focused on the large metropolitan hospitals, some thought was also given to convalescent institutions. Dr. B. J. Massiah, a veteran of the staffs of several convalescent hospitals, estimated that $£ 170,000$ was expended annually for maintenance of convalescent institutions with a total capital of $£ 4,250,000 .^{52}$ What we today call "progressive patient care" is not very far off from the vision of these men who perceived the convalescent homes as an accessory aid to hospitals. While some hospitals provided their own convalescent homes "forming an integral part of the whole machine", most hospitals did not make a conscious effort to organize formal connexions with convalescent institutions. ${ }^{53}$ One of the major problems expressed by those interested in continuing care was the attitude of some doctors who used convalescent homes as "places for the residuum", the hopeless or inconvenient patients. ${ }^{54}$

By the end of the conference, it became clear that the overriding concern of its planners had been to garner national support for a Royal Commission. In his closing remarks, Francis Powell underscored this by saying:

It should be remembered that the managers of London hospitals and infirmaries had not discovered the existence of that Conference from the newspapers, or heard of it by accident. They had all been informed of the intention to hold it, and received an invitation to attend. The Conference was therefore entitled to assume that those who had spoken were representatives of the whole, and from the fact that no speaker had offered any objection, to the proposal it might be inferred, perhaps not absolutely and legally, but certainly morally, that there was no great objection, if indeed any at all, to the appointment of the Royal Commission which it was the object of the Conference to set on foot. ${ }^{5 s}$

Individual papers by Sir Rutherford Alcock and $\mathrm{H}$. Nelson Hardy set forth the arguments for the necessity of a Royal Commission. Although a National Health Service was more than sixty years in the future, many of the conference participants were beginning to find themselves taking the first step on the path to that end. Alcock attacks local self-government advocates by saying that the principle is eminently unsatisfactory when applied to hospitals. He characterized hospitals as isolated and independent units that will not co-operate to work to any common end..$^{56}$ Like Burdett, Alcock does not commit himself on exactly what should be the State's input into the organization of hospital care. He discusses other countries with Statecontrolled hospitals and also notes that in the past the Tudor sovereigns had set the precedent by confiscating religious endowments to set up hospitals that had the power to levy taxes on the surrounding community. ${ }^{57}$ Alcock's reluctance to commit himself to State control can be seen in his concluding remarks:

How far any State control or State aid for the hospitals now in need, or to be created in the unprovided districts, might have the effect of drying up the sources of voluntary subscriptions and charitable bequests, is of course a very grave question. The tendency would seem to be in that direction, and if operative to any extent, it would no doubt form a strong argument in favour of increased voluntary efforts to make good existing deficiencies, rather than any State aid to supplement necessary income. These are matters for the consideration of a Royal Commission taken in connection with the great need for some general and improved system of control and administration. ${ }^{58}$ 


\section{Michael Millman}

Hardy's paper on the necessity of a Royal Commission summed up the general conclusion of the delegates. He reasoned that the magnitude of the problem-one million hospital patients in London, $£ 10$ million invested in metropolitan hospitals, the waste of money by the endowed hospitals, outpatients' waiting hours for valueless medicines-demanded investigation. The wide differences concerning the nature and extent of reforms combined with the lack of information in official circles, according to Holmes, had created an impossible situation that a number of professional groups had been unable to alter. In addition, the power of hospital governing boards and the independence of the endowed hospitals dampened any attempts at reform. ${ }^{59}$

Toward the end of the conference, it was resolved that the Council of the Social Science Association should invite a select group of those attending to form a committee "to secure combined action among hospitals, and to decide as to future conferences, and to take such other steps as may appear desirable ..." ${ }^{60}$ For the next several months this committee laboured to lay the foundation for what became the Hospitals Association. The inaugural meeting of this organization took place on 2 February 1884, at the Mansion House with the Lord Mayor of London presiding.

Surprisingly, the Lancet, which had earlier heralded the Hospitals Association as an "opportune and a necessary product of the day", ${ }^{61}$ expressed the fear that the Association's raison d'être was to criticize rather than help. On the other hand, the British Medical Journal predicted that the Hospitals Association would have a useful career before it. The Journal suggested that there was little hope of obtaining a Royal Commission but was confident that the Hospitals Association through private enterprise would produce a greater impact because its actions were to be continuous. ${ }^{62}$ In effect, so much effort was concentrated in the Hospitals Association that this, no doubt, contributed to the demise in 1886 of the already faltering Social Science Association.

\section{THE HOSPITALS ASSOCIATION}

The constitution of the new Hospitals Association described the goals of the body: they were to facilitate discussion on the difficulties of hospitals, to decide what measures need be taken, and then, to act. The association also intended to perform the functions of a resource centre where information could be gathered and diffused. ${ }^{63}$ Toward this end, in 1886, the association opened a London office for the collection, classification, and arrangement of facts and figures on the administration of hospitals. ${ }^{64}$

Basically, the same group of regulars active in the Social Science Association and Hospital Conference proved to be the prime mover of the Hospitals Association. Over the years, Henry Burdett delivered several papers to the Association. In 1884, he entitled his address "How can Hospital Sunday and Hospital Saturday funds be made more useful to the hospitals?". ${ }^{65}$ Apparently his attitude toward nurses softened, for he now proved to be one of the champions of the profession. Burdett was instrumental in establishing a National Pension Fund for Nurses. ${ }^{66} \mathrm{~J}$. S. Bristowe and Timothy Holmes also dealt with the problems of nursing and were concerned about the nurse training programmes in hospitals. ${ }^{67}$

Many of the issues raised at the Hospital Conference reappeared in the meetings 


\section{The Influence of the Social Science Association on Hospital Planning in Victorian England}

of the Hospitals Association. W. J. Nixon, House Governor of the London Hospital, led a discussion on the difficulties of the outpatient department. ${ }^{68}$ On another occasion the association turned to the matter of "Is it desirable that hospitals be made self-supporting, and, if so, to what extent?". ${ }^{69}$

After five years of operation, the Hospitals Association devoted a meeting to assessing the success of their organization. Bristowe, the newly elected president, pointed out that although it had not accomplished all it had set out to do, no one would deny that the association amply justified its existence. Among their accomplishments they had formed numerous special and sectional committees to examine technical problems in the art of hospital management. They also brought together diverse groups of those involved in hospital work-philanthropists, treasurers, physicians and surgeons, nurses, matrons, and the chairmen of the four largest hospitals in London..$^{70}$

Henry Burdett was present at this meeting and reliably reminded his colleagues of the work yet to be done. He still prodded the hospitals to work together to establish a uniform accounting system, and, as always, he insisted on the "creation of a power to prevent the multiplication of hospitals at localities where they were not needed, and the institution of some arrangement which would insure that every penny subscribed for medical purposes should be exactly accounted for". ${ }^{71}$

\section{THE IMPACT OF THE SOCIAL SCIENCE ASSOCIATION}

By the decade of the 1890s, the British government finally acknowledged the hospital controversy by forming the Select Committee of the House of Lords. Such a committee was not quite what the members of the Social Science Association originally envisioned. At the 1882 congress, Francis Powell warned that a parliamentary committee would not be as effective as a Royal Commission, because the former could not employ others to investigate in person at the institutions in question. ${ }^{72}$

Nonetheless, many of the prominent members of the Hospitals Associationsome of whom had been members of the Social Science Association-testified at the Lords' Committee hearings. In fact, Lord Sandhurst, chairman of the committee, would report on the progress of the investigation at the Hospitals Association meetings. ${ }^{73}$ Timothy Holmes spoke out on the outpatient departments as he had done several years earlier at the hospital conference. He told the committee that there was no need for outpatient departments, which only began sixty to eighty years earlier. Patients should either use poor law dispensaries, if they could not pay, or otherwise belong to a provident society. The outpatient department in Holmes' opinion should remain purely consultative. ${ }^{74}$

H. Nelson Hardy, who had provided the Hospital Conference with the reasons for a Royal Commission, testified before the Lords on the evils of special hospitals and on government inspection of medical institutions. ${ }^{75}$ Other members of the Hospital Association who participated in the Committee hearings were W. J. Nixon, William Blousfield, W. H. Cross, J. H. Buxton, Andrew Clark, Malcolm Morris, and, of course, Henry C. Burdett.

In character, Burdett came well prepared with his statistics. In the voluntary 


\section{Michael Millman}

hospitals of London (excluding St. Bartholomew's and St. Thomas's) there were 8,094 beds. Burdett was perceptive enough to pursue the concept of bed utilization, as well, and noted that 6,134 beds were constantly occupied during every day in the year. According to Burdett, the metropolitan hospitals managed to serve 3,800 outpatients per day. The total cost of operating these institutions was $£ 1,800$ per diem. Altogether, 6,000 employees worked in the hospital system, while 3,000 to 4,000 medical students and 1,500 nurses were being trained. Another example of Burdett's keen sense of hospital economics was exhibited by his observation that the cost of hospitals with medical schools was greater due to the class of cases treated in teaching hospitals. The problem of financing medical education with charges to patients in teaching hospitals is still a problem with the American hospital system..$^{76}$

Burdett's testimony was a medley of themes from his letters to The Times and contributions to the Social Science Association and Hospitals Association. He felt that the whole system of medical relief should be placed under voluntary, central control. The government had the right to inspect hospitals but not the right to control them. ${ }^{77}$ The greatest defect, to his mind, was the poor distribution of medical institutions. ${ }^{78}$ To remedy the situation, older hospitals should vacate their expensive sites and new hospitals should only be founded by permission and in areas of greatest need. ${ }^{79}$

The Lords' Committee's Third Report reflected many of Burdett's suggestions. They recommended a non-governmental central board, though not quite with the authority that Burdett had envisaged. The board was to collect statistics, report on plans for the establishment of new hospitals, and promote co-operation among the medical charities. ${ }^{80}$ Unfortunately, the Lords' Committee Report led to no immediate action in reforming the hospitals. Partially this may have been due to jealousy and rivalry among hospital authorities. ${ }^{81}$ Also, there was a touch of the "politics of joy" evident in the Report. For the Lancet, the Report was a reaffirmation: "the result still is that they [the hospitals] prove to be great institutions." 82

Lambert in his biography of Sir John Simon discusses the great social administrator's reliance on the Social Science Association as a forum for his ideas and a reservoir of support for his proposals. ${ }^{83}$ In much the same way Henry Burdett and his fellow hospital reformers advanced their own cause. Burdett and others had earlier sought to bring about action, but it took the Social Science Association to provide a focus for these efforts.

The Social Science Association formally ceased operations on 14 April 1886, having experienced a number of financial difficulties. ${ }^{84}$ In 1857, the association had brought together a number of separate groups. Now these groups, like the Hospitals Association, set up their own organizations, which they thought to be more effective than the amorphous parent association. ${ }^{85}$

It is difficult to evaluate the full impact of the work of the Social Science Association and its offspring, the Hospitals Association, on the evolution of health care in Britain. It would probably have astounded Burdett to learn that the British hospital system- so proudly and so fiercely based on the voluntary system-would become part of a National Health Service in just over sixty years. In retrospect, it is easier to see how conditions and events led to so great a social change, and how nicely the Social 


\section{The Influence of the Social Science Association on Hospital Planning in Victorian England}

Science Association fits into the overall pattern of change. Yet, these Victorian hospital planners only intended to improve the existing system, not start a revolution. They attempted to develop new ways of looking at hospital care. They fought for a more efficient use of resources. And they sought to educate their government and their fellow citizens.

Modern American health planners are faced with many problems analogous to those encountered by nineteenth-century Britons. It is only recently that we are even recognizing the problems inherent in a fragmentary health care system. Like the members of the Hospitals Association we attack individual problems on an individual basis, rather than overhauling the whole system. The hope invested in provident dispensaries is not unlike the faith many are now granting to the Health Maintenance Organization. The British government came to realize that it would not do to change things piece by piece. Whether Americans can successfully proceed piece by piece remains to be seen.

\section{ACKNOWLEDGEMENT}

The author would like to thank Dr. George Rosen for his invaluable guidance and editorial assistance.

\section{REFERENCES}

1. Frederic A. Ogg, 'Learned societies', in Encyclopedia of the social sciences, ed. by Edwin Seligman, New York, MacMillan, 1933, vol. 9, pp. 296-297.

2. Transactions, 1857.

3. 'The National Association for the Promotion of Social Science', The Times, 14 October 1857, p. 7.

4. Transactions, 1857 , p. 23.

5. Ibid., 1882, p. 2.

6. Ibid., 1882, p. xvii.

7. Ibid., 1857, pp. 60-61.

8. Mary Arnold, 'Basic concepts and crucial issues in health planning', Amer. J. publ. Hlth, September 1969, 59: 1686; H. E. Hilleboe, A. Barkhuus, W. C. Thomas, Jr., Approaches to national health planning, Geneva, WHO, 1972, pp. 9-12; Carl E. Taylor, 'Stages in the planning process', in Health planning, qualitative aspects and quantitative techniques, ed. by William Reinke, Baltimore, Md., Johns Hopkins University, 1972, pp. 20-34.

9. Transactions, 1857, p. 347.

10. Ibid., 1857, p. xxviii.

11. Ibid., 1857, p. 48.

12. Ibid., 1858, p. 531.

13. Ibid., 1858, p. 435.

14. Ibid., 1858, p. 442.

15. Ibid., 1858, p. 463.

16. Ibid., 1858, p. 464.

17. Ibid., 1858, p. 484.

18. Ibid., 1862, p. 622.

19. Ibid., 1863, p. 562.

20. Ibid., 1878, pp. 520-526.

21. Ibid., 1862, p. 634.

22. Ibid., 1860, p. 726. 


\section{Michael Millman}

23. Ibid., 1860 , p. 691.

24. Ibid., 1862, p. 617.

25. Ibid., pp. 647-656.

26. Ibid., 1869, p. 452.

27. The Times. 30 April 1920, p. 9 (obituary).

28. Henry C. Burdett, Hospitals and the State, London, J. A. Churchill, 1881, p. 4.

29. Ibid., pp. 4-5.

30. Ibid., pp. 5-6.

31. Ibid., pp. 6-7.

32. Ibid., pp. 7,11 .

33. Ibid., pp. 8-10.

34. Ibid., p. 11.

35. Hospital management: being the authorized report of a conference on the administration of hospitals, ed. by J. L. Clifford-Smith, London, Kegan, Paul, Trench, 1883, pp. 183-192.

36. Transactions, 1882 , p. 393.

37. Ibid., p. 395.

38. 'A hospital conference', The Times, 23 April, 1878, p. 8.

39. 'The hospitals of London', The Times, 22 March 1879 p. 9.

40. 'Hospital administration', Lancet, 31 March 1883, p. 552.

41. Hospital management, op. cit., p. 171.

42. Ibid., pp. 10-11.

43. Ibid., pp. 14-21.

44. Ibid., p. 23.

45. Ibid., p. 32.

46. Ibid., pp. 40-41.

47. Ibid., p. 42.

48. Ibid., p. 75.

49. Ibid., pp. 74-75.

50. Ibid., p. 88.

51. Ibid., pp. 96, 101-103.

52. Ibid., p. 133.

53. Ibid., p. 134.

54. Ibid., p. 139.

55. Ibid., p. 170.

56. Ibid., p. 141.

57. Ibid., pp. 150-151.

58. Ibid., pp. 151-152.

59. Ibid., pp. 152-156.

60. Ibid., p. 171.

61. 'Hospitals Association', Lancet, 17 November 1883, p. 873.

62. 'The Hospitals Association', Br. med. J., 9 February 1884, p. 282.

63. 'Hospitals Association', Lancet, 17 November 1883, p. 886.

64. 'Hospitals Association', Br. med. J., 24 April 1886, p. 793.

65. 'Hospitals Association', ibid., 24 May, 1884, p. 1013.

66. 'The Hospitals Association', ibid., 2 June 1884, p. 1193.

67. 'The Hospitals Association', ibid., 26 April 1884, p. 831,

68. 'Hospitals Association', ibid., 29 March, 1884, p. 625.

69. 'Hospitals Association', ibid., 21 June 1884, p. 1224.

70. 'The Hospitals Association', The Times, 17 October 1889, p. 10.

71. Ibid., p. 10.

72. Transactions, 1882 , p. 442.

73. 'The Hospitals Association', The Times, 20 June 1892, p. 11.

74. 'Report From the Select Committee of the House of Lords on Metropolitan Hospitals 
The Influence of the Social Science Association on Hospital Planning in Victorian England

with Minutes of Evidence, Appendix, and Index, 1890', British Parliamentary Papers, Shannon, Ireland, Irish University Press, 1970, vol. 12, pp. 49-55.

75. Ibid., vol. 12, pp. 57-80.

76. Ibid., vol. 13 , pp. 713-738.

77. Ibid., pp. 719-720.

78. Ibid., p. 724.

79. Ibid., p. 726.

80. 'Third Report of the Lords' Committee upon Metropolitan Hospitals', Lancet, 5 November 1892, p. 1066.

81. Brian Abel-Smith, The hospitals of England and Wales, 1800-1948, Cambridge, Mass., Harvard University Press, 1964, p. 173.

82. Lancet, 12 November 1892 , p. 1109.

83. Royston Lambert, Sir John Simon 1816-1904 and English social administration, London, MacGibbon \& Kee, 1963, p. 300.

84. 'Social Science Association', The Times, 16 April 1886, p. 8.

85. B. Rodgers, 'The Social Science Association, 1857-1886', The Manchester School of Economics and Social Studies, vol. 20, no. 3, September 1952. 